\title{
Testing satellite telemetry within narrow ecosystems: nocturnal movements and habitat use of bottlenose dolphins within a convoluted estuarine system
}

\author{
Elizabeth F. Hartel', Wendy Noke Durden ${ }^{2}$ and Greg O'Corry-Crowe ${ }^{3^{*}}$ (i)
}

\begin{abstract}
Background: While cetaceans have been extensively studied around the world, nocturnal movements and habitat use have been largely unaddressed for most populations. We used satellite telemetry to examine the nocturnal movements and habitat use of four bottlenose dolphins (Tursiops truncatus) from a well-studied population in a complex estuary along the east coast of Florida. This also enabled us to explore the utility of satellite tracking on an apex predator within a very narrow and convoluted ecosystem. Our objectives were to evaluate (1) nocturnal home ranges and how individual dolphins moved within them, (2) nocturnal utilization of habitats surrounding ocean inlets, (3) nocturnal movements outside of the population's known range (i.e., the study area), and (4) nocturnal use of select environmental variables.
\end{abstract}

Results: Satellite tags were active between 129 and 140 days (136 4 4.99) during nocturnal hours (summer/fall 2012), yielding $3.3 \pm 1.4$ high-quality transmissions per night. Results indicated substantial individual variation among the four tagged dolphins, with home ranges varying in length from 53.9 to $83.6 \mathrm{~km}(\bar{x}=71.9 \pm 12.9$ ). Binomial tests and MaxEnt models revealed some dolphins preferred habitats surrounding inlets, seagrass habitats, and various water depths, while other dolphins avoided these areas. All dolphins, however, showed substantial movement $(\bar{x}=5.8 \pm 7.4 \mathrm{~km})$ outside of the study area, including travel into rivers/canals and the adjoining ocean (6.0-8.6\% and $0.8-2.9 \%$ of locations per dolphin, respectively).

Conclusions: This study was the first to utilize satellite telemetry on Indian River Lagoon dolphins and provided the first detailed insights into the nocturnal movements and habitat use of this population. Our findings suggest that while individual dolphin home ranges may overlap, they use different foraging strategies, feed on different prey, and/ or exhibit intraspecific resource partitioning. In contrast with a prior study, all tagged dolphins showed considerable movement into the adjoining ocean and freshwater sources. This suggests this population has a much larger range than previously thought, which is important to consider for future research and conservation efforts.

Keywords: Bottlenose dolphin, Nocturnal movement, MaxEnt, Indian River Lagoon, Satellite telemetry

*Correspondence: gocorryc@fau.edu

${ }^{3}$ Harbor Branch Oceanographic Institute at Florida Atlantic University, 5600 US 1 North, Fort Pierce, FL 34946, USA

Full list of author information is available at the end of the article

\section{Background}

The investigation of nocturnal behavior and ecology in wild populations is often challenging yet critical to developing a complete understanding of behavioral ecology and conservation needs. Nocturnal, and even crepuscular, research is especially limited for wild cetaceans. In a

c) The Author(s) 2020. This article is licensed under a Creative Commons Attribution 4.0 International License, which permits use, sharing, adaptation, distribution and reproduction in any medium or format, as long as you give appropriate credit to the original author(s) and the source, provide a link to the Creative Commons licence, and indicate if changes were made. The images or other third party material in this article are included in the article's Creative Commons licence, unless indicated otherwise in a credit line to the material. If material is not included in the article's Creative Commons licence and your intended use is not permitted by statutory regulation or exceeds the permitted use, you will need to obtain permission directly from the copyright holder. To view a copy of this licence, visit http://creativeco mmons.org/licenses/by/4.0/. The Creative Commons Public Domain Dedication waiver (http://creativecommons.org/publicdomain/ zero/1.0/) applies to the data made available in this article, unless otherwise stated in a credit line to the data. 
number of recent studies on small cetaceans, nocturnal habits were sometimes found to differ substantially from diurnal behavior [1-3]. Studies of offshore bottlenose dolphins in Bermuda found nocturnal behavior was often characterized by long, deep dives corresponding with nightly vertical migrations of mesopelagic prey [2]. In the Bahamas, Atlantic spotted dolphins (Stenella frontalis) inhabiting coastal inshore waters also move further offshore into deep waters to forage at night [4]. By contrast, in Brazil, nocturnal behaviors of estuarine Guiana dolphins (Sotalia guianensis) did not differ significantly from those documented during the day [1]. Therefore, nocturnal and diurnal movements and behaviors may differ or overlap, depending upon the population and perhaps the available habitat and/or prey species. Satellite telemetry is potentially a powerful tool in the study of the nocturnal habits of small cetaceans, but few such studies have been published to date [2].

As with nocturnal studies, the tracking of highly mobile predators in convoluted habitats is often challenging. This is especially so with marine species, including cetaceans, that inhabit complex coastal habitats such as estuarine systems. Most cetacean studies employ techniques that require line-of-sight from a horizontal or near-horizontal plane (e.g., visual observations, photo-ID and radio-telemetry from small boats or shore, and passive acoustic monitoring from small boats) [5-10]. Such approaches have limitations in shallow, convoluted habitats, such as estuarine and lagoon systems and often lack flexibility to enter open ocean waters [11]. Satellite telemetry can provide improved access to animals and their activities in narrow complex habitats. Here, we report on the nocturnal movements and habitat use of bottlenose dolphins in a shallow, convoluted coastal system.

Bottlenose dolphins (Tursiops sp.) are among the most coastal of all cetaceans, with a number of populations occupying habitats such as shallow, brackish waters [12-14], embayments [15, 16], and areas in close proximity to centers of human populations [17]. Much has been learned about diurnal foraging ecology $[16,18]$, habitat use [19-21], and ranging patterns [15, 22, 23] of coastal and estuarine populations, which can vary widely based upon location [24], season [25], and sex [16, 26]. Many of these populations face numerous direct and indirect anthropogenic threats, including contaminants [27, 28], human disturbance [29-32], and injury (e.g., vessel strikes [33, 34] and entanglement [35-37]).

A versatile species, bottlenose dolphins, exhibit high variability in most aspects of behavioral ecology. Some coastal populations have been found to prefer foraging on fish species associated with seagrass [16, 38], while others showed little preference for seagrass habitat [18]. Likewise, some populations may prefer deeper waters
[24] and dredged channels [18], while others forage more in shallow waters during seasonal periods when shark predation risk is low [20]. Many dolphin populations also exhibit individual variation in habitat use, making understanding habitat utilization even more complex. In the Indian River Lagoon, Florida, USA, previous research found variation in water depth usage of radio-tagged dolphins and an overall higher than expected usage of the deeper waters (i.e., $>1 \mathrm{~m}$ ) in a very shallow system [8]. In Shark Bay, Australia, individual differences in habitat use were related to certain foraging tactics, and these tactics were correlated with seagrass biomass, water depth, presence of marine sponges, and season [39, 40]. Similarly, in Florida Bay, individual dolphins specialized in a single foraging tactic and overall distribution patterns were linked to habitats which supported the corresponding tactic [41]. Almost all aforementioned studies, however, occurred during daylight and only a few occurred where the shallowest and most complex habitats made tracking difficult [12]. Consequently, nocturnal behaviors in convoluted areas have been largely unaddressed. Some nocturnal surveys have been conducted using moonlight luminance for visual observation [1], while other studies have used acoustics [1,10]. Both methods, however, are extremely difficult to apply in labyrinthine and shallow habitats where bathymetric and topographic obstacles greatly inhibit detections and observations. Satellite telemetry potentially offers an efficient solution to many limitations and challenges where previous studies have struggled. As of this writing, we could only find one prior study that used satellite telemetry to investigate nocturnal movements of bottlenose dolphins [2], and it focused on movement and dive behavior of an offshore population.

We present findings from a satellite telemetry study of bottlenose dolphin nocturnal ranging patterns and habitat use in a shallow, estuarine system on the east coast of Florida, USA: the Indian River Lagoon (IRL) (Fig. 1). Characterized by expansive shallows and a convoluted shoreline with many branching channels, much of the Indian River Lagoon presents significant challenges to traditional dolphin research methods. The IRL is a diverse ecosystem of brackish water, once boasting the highest seagrass diversity of any US estuary [42]. In recent years, however, the estuary has undergone significant ecological disturbances (i.e., phytoplankton blooms) yielding a catastrophic loss of nearly $50 \%$ of seagrass habitat in 2011 [43]. The estuary also has a high diversity of wildlife, including 685 species of fish, 370 species of birds [44], and at least six distinct communities of bottlenose dolphins [7].

Bottlenose dolphins from the Indian River Lagoon estuarine system stock are year-round residents of the 


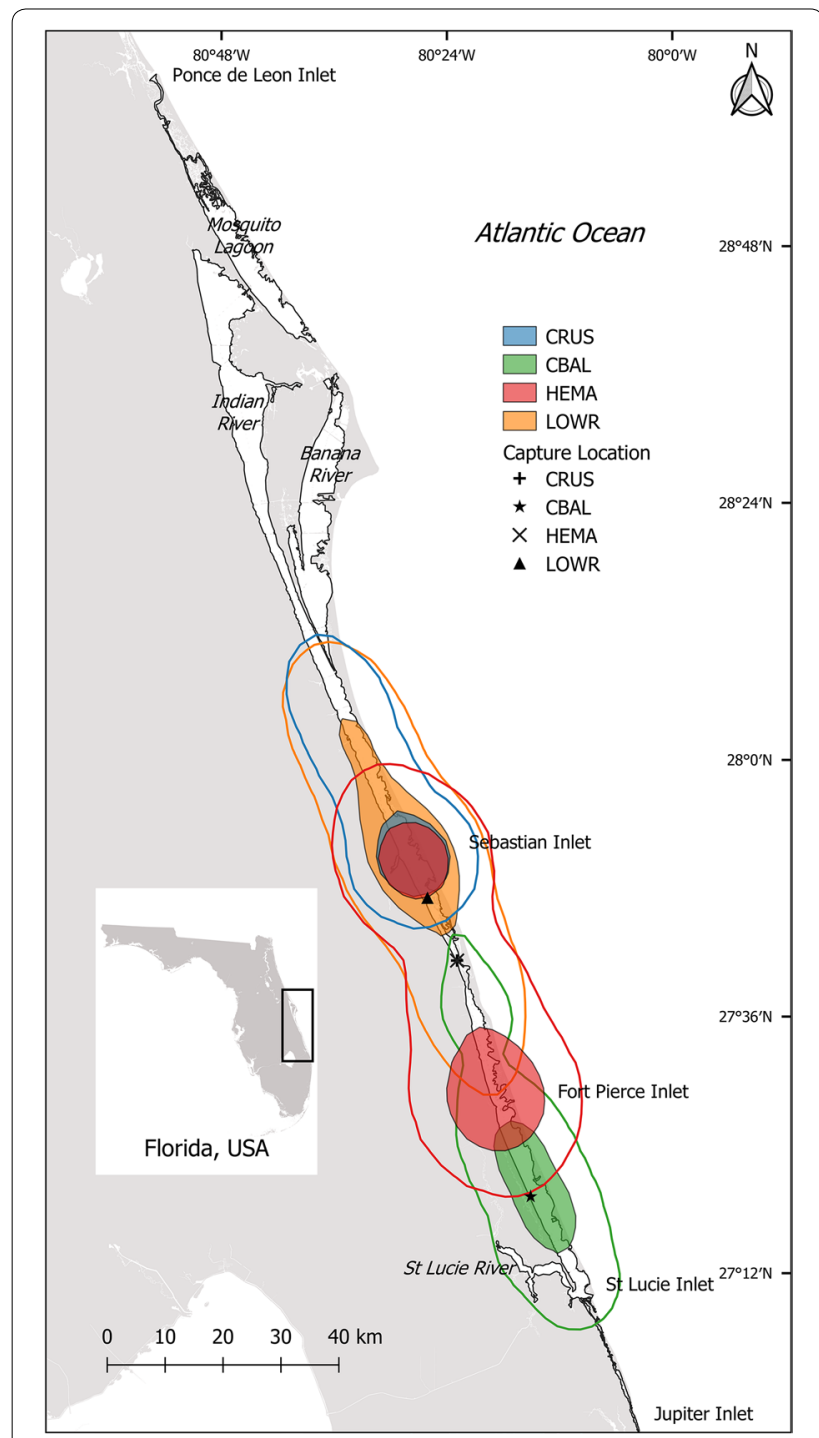

Fig. 1 Map of the study area showing the entire Indian River Lagoon (black outline). Insert indicates lagoon's location within Florida. Overlapping home ranges and core areas for individual bottlenose dolphins $(n=4)$ determined using nocturnal satellite telemetry locations are shown. Lines indicate 95\% home range and solid shapes show $50 \%$ core areas for each dolphin. Black shapes indicate capture locations for each dolphin (CRUS and HEMA caught together). Grey denotes land

IRL [45]. Overall, dolphins exhibit high site fidelity, and abundance within the main IRL system may fluctuate seasonally (summer 483, winter 1947, mean 1032) [46]. The population faces many direct and indirect threats including boat strikes [33], entanglements [37], and environmental contamination [27, 43]. While the IRL dolphin population has been extensively studied, including a long-term photo-identification program [7, 47-49], the use of aerial line-transect surveys [46, 50], and limited radio-telemetry $[8,51]$, previous information on nocturnal movement was virtually nonexistent (a single study used short-term Trac Pac tags and stomach temperature pills for limited nocturnal comparisons [52]). As such, we were interested in detailed nocturnal movements and habitat use to gain a more complete ecological understanding of this population. In specific, our objectives were to evaluate (1) nocturnal home ranges and how individual dolphins moved within them, (2) nocturnal utilization of habitats surrounding inlets between the estuary system and the Atlantic Ocean, (3) whether dolphins travelled outside the population's known range at night (i.e., the Indian River Lagoon), and (4) whether dolphins exhibited nocturnal preferential use of select environmental variables found to be important in other populations, including seagrass habitat and water depth.

\section{Results}

In June 2012, we tagged four juvenile/adult male dolphins ranging in age from 6 to 21 years. All four satellite tags were functioning and transmitting data from approximately mid June through early November 2012 (Table 1). Satellite tags remained active between 129 and 140 days $(136 \pm 4.99)$ and tag failure was due to either battery failure or delrin pin shearing/nut loss (none of the tags migrated through the dorsal fin tissue). The mean highquality transmissions per date varied from 2.7 to 3.5 . After the data were trimmed to help reduce autocorrelation ( $\geq 1 \mathrm{~h}$ apart), 126-184 (163 \pm 25.79$)$ data points were removed for each dolphin (653 total) and the mean transmissions per date was reduced to $1.7-2.2$. Nocturnal data, defined as between 18:00 and 06:00, made up $98.0-100 \%$ of each dolphin's data (Table 1). Due to the shallowness of the IRL, the maximum number of tag transmissions was typically reached between midnight and 04:00 each day (96.7-99.3\% of each dolphin's data).

The radio tag placed on HEMA functioned from midJune through early-August (at least 45 days). Observations during that time period indicated the animal and both tags were in good condition with no visual evidence of tag migration. On 24 August (66 days after deployment), HEMA was seen with both tags still attached, but the VHF transmitter was no longer functioning.

\section{Individual home range use}

The four dolphins had overlapping home ranges that extended the entire southern half of the IRL system (Fig. 1). Given the shape of the study area, the estimated kernel density home ranges of all dolphins were quite linear; however, the realized home ranges were even more linear when only aquatic habitat was considered. Using this latter metric, CRUS had the smallest home range and core area length (53.9 and $14.9 \mathrm{~km}$, respectively) while 


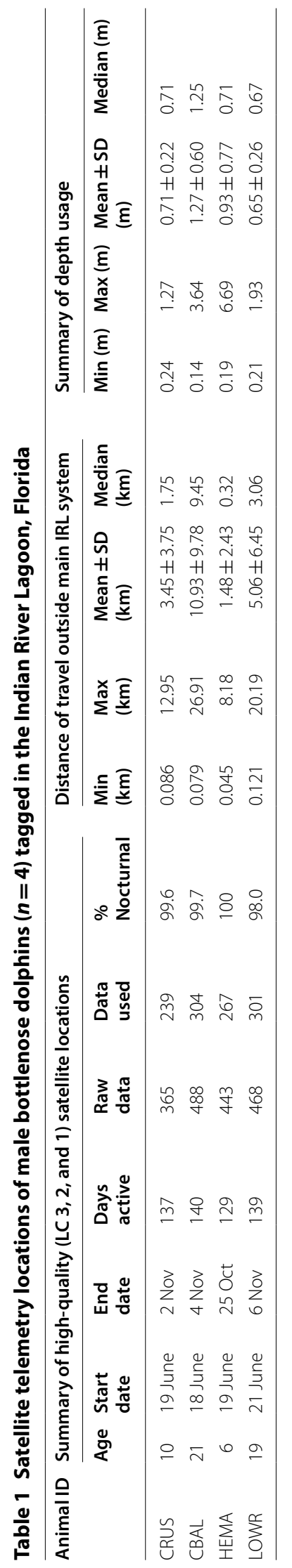


LOWR had the largest (83.6 and $41.1 \mathrm{~km}$, respectively). Each dolphin had a single core area within their home range, except HEMA who had two distinct core areas. Evaluation of Universal Transverse Mercator (UTM) Northing by date indicated two different movement patterns (Fig. 2). CRUS and HEMA tended to stay in the same area for several days before transiting to a different area, whereas CBAL and LOWR showed larger movements on nearly a daily basis (Fig. 2). In addition, while the dolphins' home ranges and core areas overlapped substantially in space (Fig. 1), the dolphins themselves did not often overlap in time (Fig. 2). This is particularly striking between HEMA and CRUS as they both showed frequent use of Sebastian Inlet, but were only occasionally there on the same date.

\section{Travel outside the main IRL system}

Even after rigorous $\mathrm{QA} / \mathrm{QC}$, all four dolphins showed considerable movement outside of the main IRL system (Figs. 3, 4, Table 1). These results likely represent the minimum extent of travel outside of the IRL by these dolphins (see "Methods" section). The distance travelled outside of the IRL varied dramatically; however, all four dolphins showed long trips either up rivers/creeks or out into the ocean (Table 1).

\section{Habitat selection}

All four dolphins' home ranges encompassed at least one inlet to the ocean and three dolphins' core areas included an inlet. HEMA was particularly interesting as both of the dolphin's nocturnal core areas centered around inlets (Fig. 1). The results of the binomial tests indicated CRUS $(p<0.0001)$, HEMA $(p<0.0001)$, and LOWR $(p<0.0001)$ all used inlet habitat significantly more than expected based upon the amount of their home range that was near an inlet (Fig. 5a). The remaining dolphin, CBAL, did not appear to use inlets more than expected $(p=0.3209)$. These findings are also evident in the pattern of north-south movements for each dolphin where three of the four individuals spent considerable time near inlets, with one, HEMA, often moving between Fort Pierce and Sebastian Inlets (Fig. 2).

For the detailed seagrass analyses, the results of the binomial tests indicated CRUS $(p=0.0022)$ was found in seagrass habitat significantly more, and CBAL $(p=0.0326)$ was found in seagrass significantly less than expected based upon the amount of their home ranges consisting of seagrass (Fig. 5b). In contrast, HEMA's $(p=0.3329)$ and LOWR's $(p=0.1806)$ occurrence in seagrass habitat did not differ from expectations.

Summary statistics for depth usage for each dolphin are reported (Table 1); it is important to note the entire IRL system is extremely shallow ( $82 \%$ of the IRL is $<1 \mathrm{~m}$ deep). Individual binomial tests indicate some animals showed depth preference/avoidance. CRUS used $<1 \mathrm{~m}$ depths significantly more $(p=0.0134)$ and $1-2 \mathrm{~m}$ depths significantly less $(p=0.0134)$ than expected based upon the availability of these habitats within the dolphin's home range (Fig. 5c). By contrast, CBAL utilized $<1 \mathrm{~m}$ depths significantly less $(p<0.0001), 1-2 \mathrm{~m}$ depths significantly more $(p<0.0001)$, and $2-3 \mathrm{~m}$ depths significantly more $(p=0.0308)$ than expected based upon habitat availability (Fig. $5 \mathrm{c}$ ). At $<1 \mathrm{~m}$ depths, HEMA's results were not quite significant $(p=0.0573)$, but the animal utilized 1-2 $\mathrm{m}$ depths significantly more than expected ( $p=0.0002)$ (Fig. 5c). LOWR used $<1 \mathrm{~m}$ depths significantly more $(p=0.0005)$ than expected, but $1-2 \mathrm{~m}$ results were not significant $(p=0.0689)$ (Fig. 5c). CRUS and LOWR did not have any locations in either of the two deeper depth categories. HEMA was not significant in either of the deeper depth categories $(2-3 \mathrm{~m}$ :

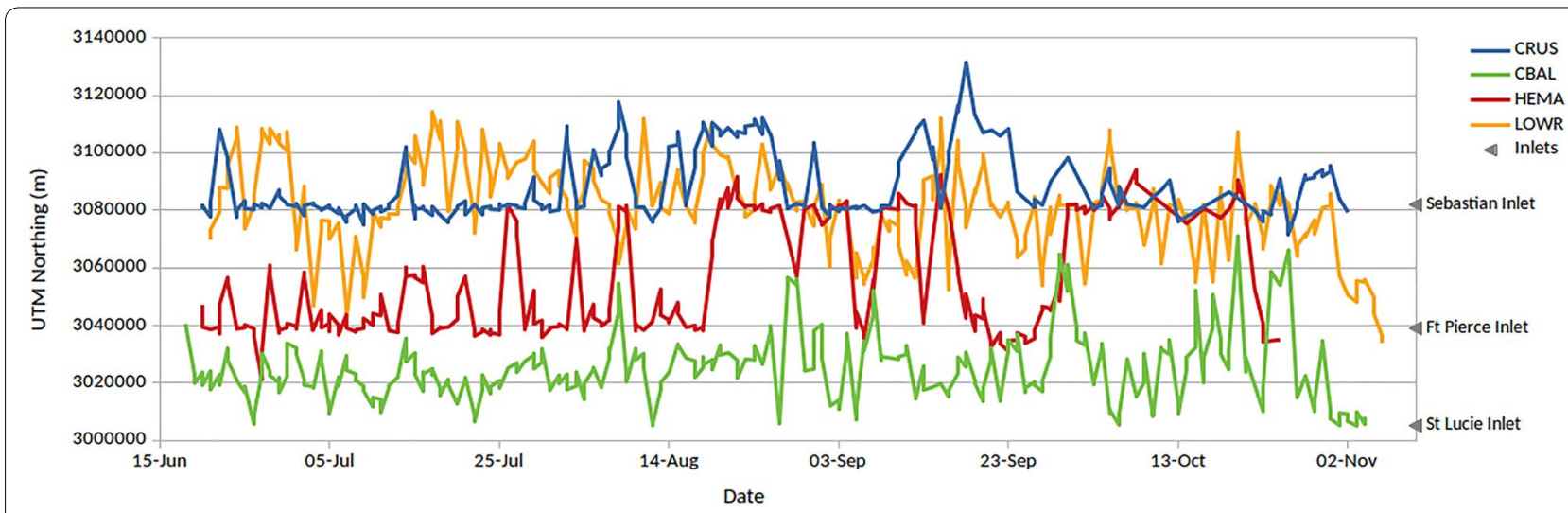

Fig. 2 UTM Northing vs Date for male bottlenose dolphins $(n=4)$ within the Indian River Lagoon using satellite telemetry data. Grey arrows mark the location of inlets on the secondary $y$ axis 


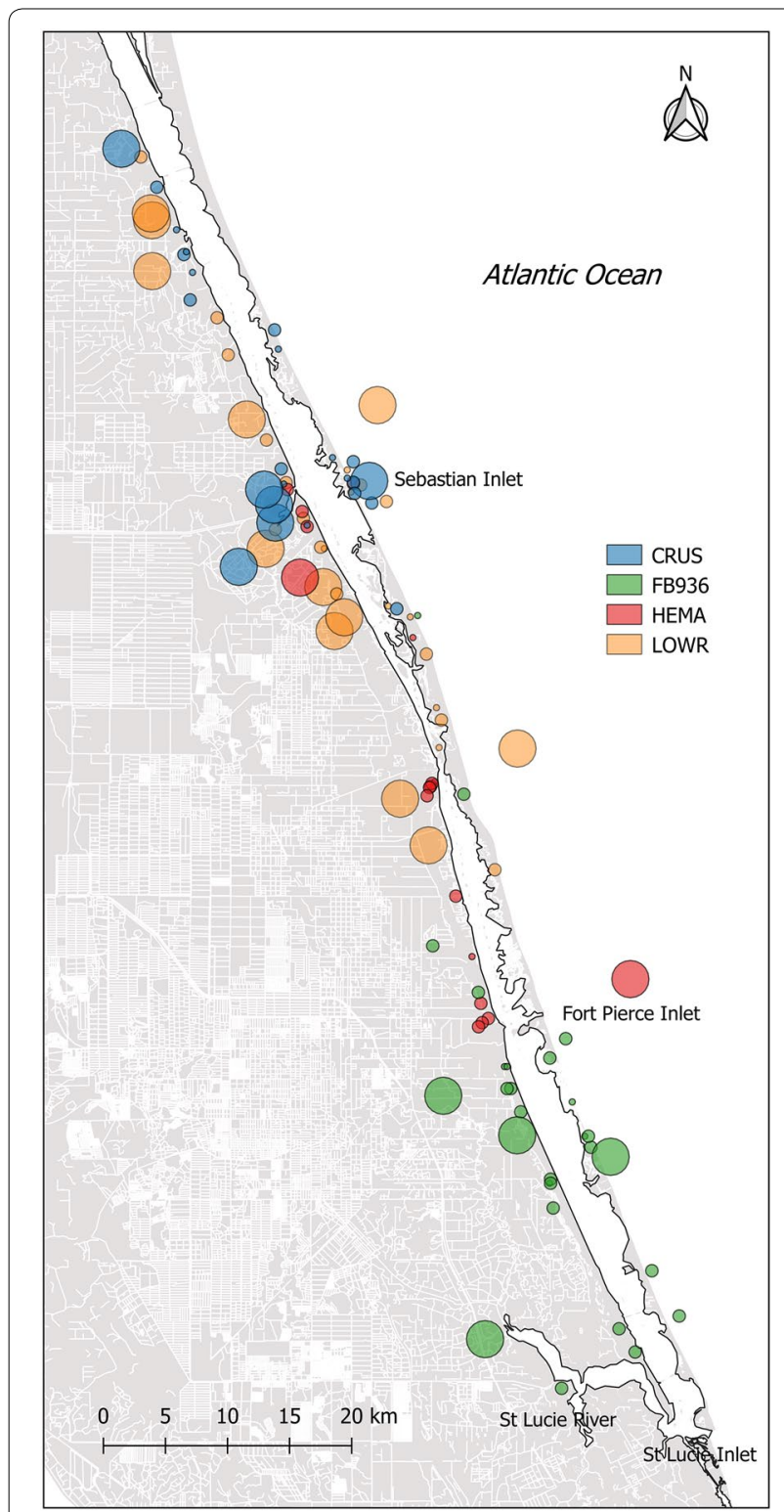

Fig. 3 Bottlenose dolphin $(n=4)$ satellite telemetry data points where the potential error does not overlap the Indian River Lagoon (black outline).White lines mark the freshwater rivers, creeks, and canals connected to the IRL. Grey denotes land

$p=0.3044,>3 \mathrm{~m}: p=0.1438)$ and CBAL $(p=0.1024)$ did not show significance at $>3 \mathrm{~m}$ depths.

\section{Ecological niche modeling}

The MaxEnt analysis generated models with training and test AUC (area under the receiver operating curve) values very close to 1.0 (i.e., $0.970-0.982$ ) indicating high model performance and thus high confidence in the resulting modeled suitability of habitat for each animal. A representation of the modeled habitat suitability for each dolphin is presented (Fig. 6) and response curves for each environmental variable and graphic outputs of the jackknife analyses of variable importance are reported (Additional file 1). In general, moderate to highly suitable conditions primarily comprised long stretches of habitat centered in the IRL within the dolphins' home ranges, with better predicted areas more patchily distributed (Fig. 6). In all cases, areas outside the main IRL system were identified as preferred habitat (Fig. 6). It is important to note that some of the variables examined may be correlated or may interact in some manner, such as all the monthly sea surface temperatures (SST) and dissolved oxygen (DO) measurements, and this should be borne in mind when interpreting how each individual environmental variable affects MaxEnt predictions.

The MaxEnt results for both CRUS (AUC $=0.979$ ) and HEMA (AUC $=0.981$ ) indicated that distance from inlets and seagrass distance were the two most important model variables explaining their distribution (jackknife analysis of variable importance, Additional file 1). Response curves indicated the model output decreased as distance from both features increased (highest output for both was at near zero distances, see Additional file 1). For CBAL (AUC=0.970), SST-Sept and seagrass distance were the most important variables according to jackknife analyses (Additional file 1). Response curves indicated higher model output at small non-zero distances from seagrass and at mid-range temperatures. Since the monthly SST values are all correlated, Sept is likely not any more important than the other months. For LOWR (AUC $=0.972$ ), according to jackknife analyses seagrass distance and type of water body were the most important variables. Response curves indicated highest output at near zero distance from seagrass and within the brackish waters of the IRL (Additional file 1). Maxent also identified other variables of importance depending upon whether the jackknife was using training gain (above results), test gain, or AUC (see Additional file 1). Other potentially important variables include DO-July for CRUS, DO-Nov for CBAL, and DO-July for LOWR. HEMA's top two variables remained consistent throughout all types of jackknife tests.

\section{Discussion}

Despite the growing wealth of research on coastal cetacean species, there remains a dearth of information on nocturnal habits. Neglect of this aspect of cetacean ecology results in an incomplete understanding of behavioral ecology and population drivers and prevents comprehensive assessments of species risk and conservation needs. This study provided unique insights into the behavioral ecology of bottlenose dolphins in an estuarine system during the overnight hours and may be 


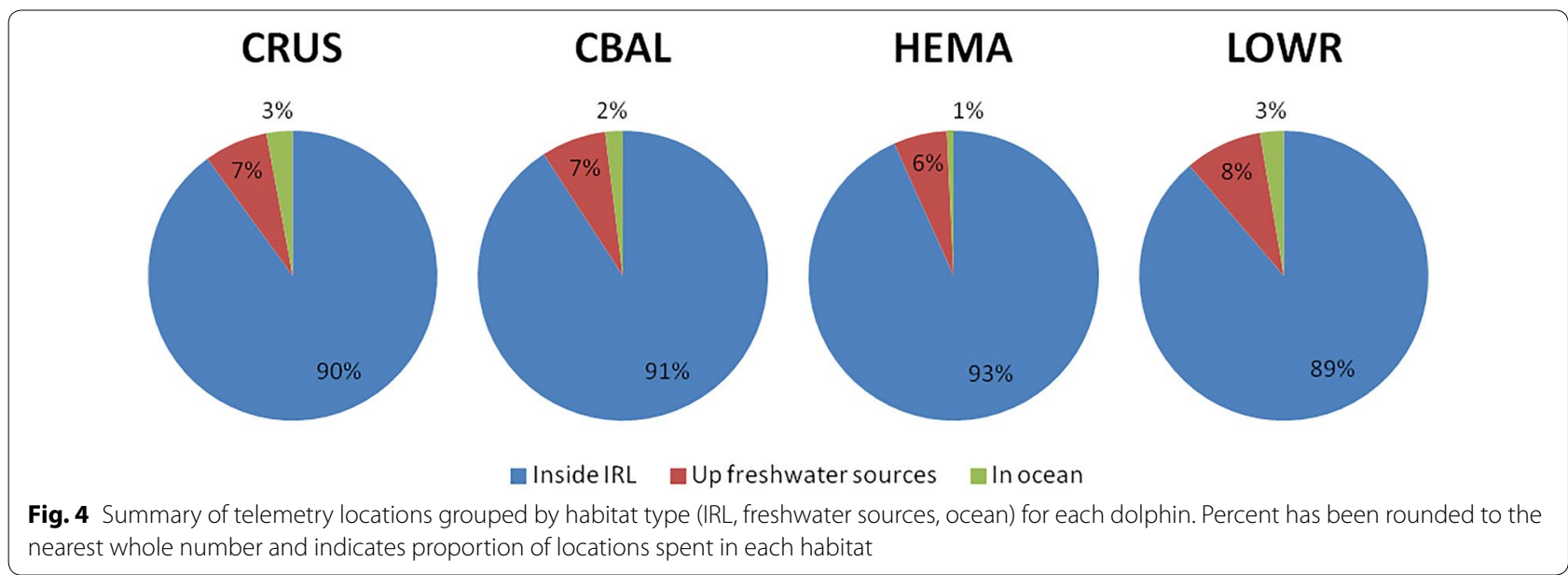

the first investigation of the nocturnal movements and habitat use of a coastal dolphin population via satellite telemetry. This study documented for the first time that Indian River Lagoon dolphins regularly leave the brackish waters of the estuarine system and travel not only into the ocean, but also up rivers, creeks, and freshwater canals. The investigation also discovered extensive individual variation in ranging patterns and niche preferences. Collectively, these findings highlight the need for greater consideration of the nocturnal habits of cetacean species when conducting risk assessments, developing conservation action, and planning new research.

This study also highlights the amount of variation that can occur within a population, as we found individual variation with almost every aspect studied. Individual spatial use varied by dolphin, with home ranges and core areas of different sizes spaced throughout the southern region of the IRL. Variation in how individual dolphins moved within their home ranges was also evident. CRUS and HEMA had similar movement patterns. These two dolphins would make small localized movements for several days and then make a larger move to a different part of their home range. In contrast, CBAL and LOWR rarely stayed in one place and instead showed consistent, larger movements on an almost nightly basis. There are many possible reasons for the difference in space use and movement patterns, including prey preference and distribution (i.e., traveling between nearby hotspots vs long distances between food sources), or size/age (i.e., CRUS and HEMA were smaller/younger while CBAL and LOWR were larger/older). In a previous study on the IRL dolphin population, a juvenile dolphin was found to travel smaller linear distances and exhibit play and social behaviors more than the adults [8]. At 10-year old, CRUS was on the cusp of becoming an adult while LOWR was twice the age; therefore, the difference in movement patterns between CRUS and LOWR despite substantial home range overlap is likely not due to habitat, but more complex factors possibly linked to age and/or social dynamics. Similarly, the use of satellite telemetry found two distinct ranging patterns among 19 tagged bottlenose dolphins within the Mississippi Sound where some dolphins frequented the barrier islands and others used inshore waters more often [53].

Individual dolphins also exhibited preferences for various habitat types. CRUS appeared to prefer extremely shallow waters $(<1 \mathrm{~m}$ deep) containing seagrass, while CBAL preferred mid-range depths (1-2 $\mathrm{m}$ and 2-3 $\mathrm{m}$ ) without seagrass. LOWR appeared to prefer extreme shallows while HEMA preferred 1-2 m depths, but neither showed seagrass habitat preference. The MaxEnt model results mostly corresponded with our detailed analysis of seagrass. As seagrass is patchily distributed throughout the IRL, the distances from seagrass are relatively small unless the dolphin is outside of the IRL; therefore, even though CBAL's model indicated usage at small distances from seagrass, those distances were nonzero and thus the dolphin still may have been avoiding seagrass. These differences in depth and seagrass preference/avoidance may be linked to predator avoidance or individual prey preference. In Shark Bay, the risk of shark predation appeared to be greater in shallower water [20]; CBAL and HEMA may be avoiding extreme shallows as a measure of predator avoidance. Furthermore, the IRL is a known bull shark (Carcharhinus leucas) nursery, and young/juvenile sharks are often found in shallow $(\sim 1 \mathrm{~m})$ waters and seagrass beds during the spring, summer, and fall [54]. Shark abundance also decreases with increasing latitude within the IRL [54]. CRUS and LOWR's home ranges are further north, thus the shallows and/or seagrass may be less risky for them due to lower shark density. Seagrass beds in the IRL are a rich habitat harboring 

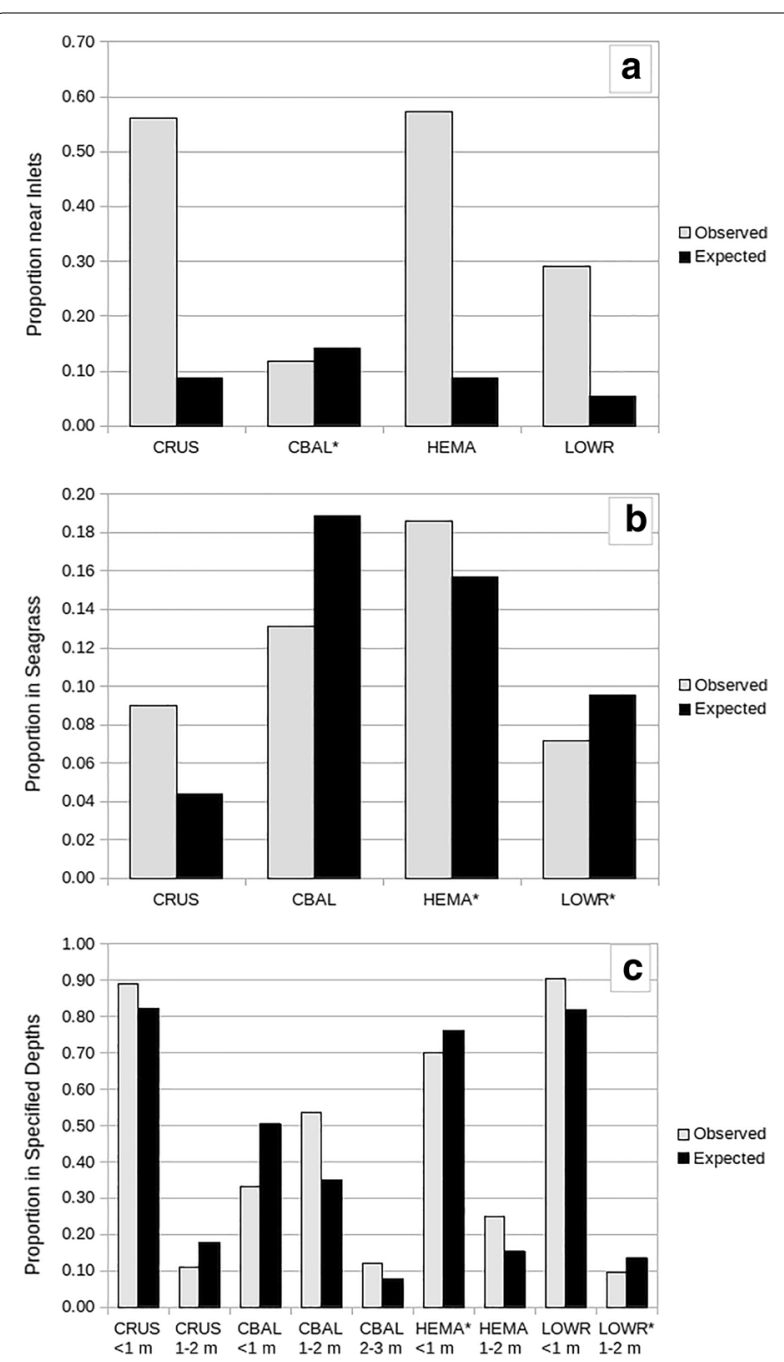

Fig. 5 Observed vs expected proportions of locations a near inlets, $\mathbf{b}$ in seagrass habitat, and $\mathbf{c}$ within specified depths. Grey denotes observed and black denotes expected values. Asterisk indicates non-significant result. a CRUS: $p<0.0001$, CBAL: $p=0.3209$, HEMA: $p<0.0001$, LOWR: $p<0.0001, \mathbf{b}$ CRUS: $p=0.0022$, CBAL: $p=0.0326$ HEMA: $p=0.3329$, LOWR: $p=0.1806, \mathbf{c}$ CRUS $<1 \mathrm{~m}: p=0.0134$, CRUS $1-2 \mathrm{~m}: p=0.0134, \mathrm{CBAL}<1 \mathrm{~m}: p=<0.0001, \mathrm{CBAL} 1-2 \mathrm{~m}: p<0.0001$, CBAL 2-3 m: $p=0.0308$, HEMA $<1 \mathrm{~m}: p=0.0573$, HEMA $1-2 \mathrm{~m}$ : $p=0.0002$, LOWR $<1 \mathrm{~m}: p=0.0005$, LOWR 1-2 m: $p=0.0689$

over 200 species of fish [55], thus CRUS's preference for seagrass could be linked to prey availability, while CBAL's preferred prey species may not inhabit seagrass habitat. CBAL and HEMA's depth preferences corresponded with Durden et al. [8] who found radio-tagged IRL dolphins selected $>1 \mathrm{~m}$ depths more than expected based upon habitat availability; however, CRUS and LOWR showed the opposite. Durden et al. [8] also found foraging and play behavior occurred more in extreme shallows. Perhaps CRUS and LOWR were foraging more often when satellite locations were recorded. Foraging strategy often varies by habitat type [41], so perhaps CBAL and HEMA have preferred foraging strategies best employed in midrange depths while CRUS and LOWR's preferred strategy is best in extremely shallow waters. In all likelihood, some combination of the above factors dictates individual habitat selection.

An estimated 1032 bottlenose dolphins $(95 \% \mathrm{CI}=809$ to 1255) reside in the IRL [46]. With such a large population sharing such a shallow and narrow (tag deployment area) habitat, perhaps intraspecific resource partitioning is occurring. Resource partitioning is a common way for sympatric species to coexist in the same habitat. In Australia, snubfin dolphins preferred shallower areas with seagrass while humpback dolphins preferred slightly deeper waters and dredged channels [56]. Similarly, in the western gulf of Shark Bay, non-sponging bottlenose dolphins forage more often in shallow areas with seagrass while sponging dolphins forage in deep channels without seagrass. Both of these findings are very similar to the differences in habitat selection observed between CRUS and CBAL. Resource partitioning could help explain both the individual preferences in habitat selection and differences in movement patterns: individual dolphins are essentially using different habitats and eating different prey species which helps increase the carrying capacity and reduce direct competition between dolphins within the IRL. This theory is supported by comparable mean IRL dolphin abundance estimates over $\sim 10$ years (Durden et al. personal communication) which suggest a stable population at or nearing carrying capacity. More research and larger sample sizes are needed to truly determine the extent of variation and impacts these environmental characteristics have on this population.

One of the areas showing less variation is inlet use. Three out of four dolphins exhibited a strong nocturnal preference for habitats close to inlets, with one individual regularly using multiple inlets. Inlets may be important nocturnal foraging habitats as well as corridors for movement between ecosystems. Inlets are some of the deepest waters within the IRL (which may vary in importance considering the results of our depth analyses) and host a diverse fish community: 280 fish species have been documented within the inlets of the IRL [55]. IRL dolphins are also often seen foraging near many of the inlets (person observation). Similar preferences have been documented in other dolphin populations $[15,24,57]$, indicating the mouths/inlets of estuaries and bays are often important habitat for dolphins. In some populations, echolocation appears to be used more frequently during feeding [58]; therefore, future research using passive acoustic monitoring at the inlets may help reveal whether the use of inlets is, in fact, linked to foraging. 


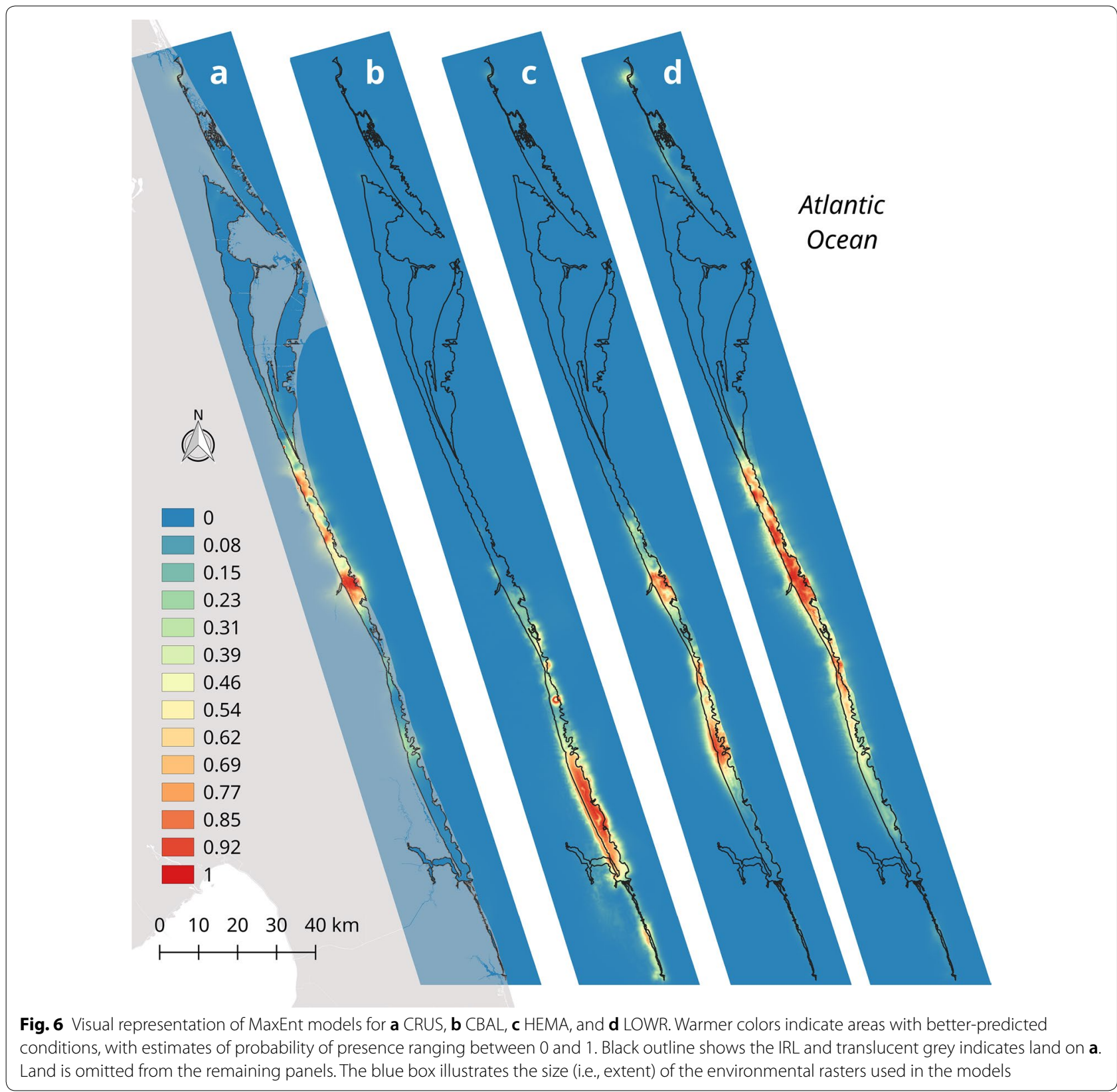

A recent diurnal study of nine radio-tracked dolphins [8] found that, on average, IRL tagged dolphins spent the majority of time traveling (53\%) and only $17 \%$ foraging, with some individuals spending up to $80 \%$ of time traveling. Furthermore, diurnal travel occurred more often in the deepest waters $(>3 \mathrm{~m})$ [8]. Our results found no connection between nocturnal movements and the deepest waters suggesting IRL dolphins may not travel much at night. Collectively, these findings reveal that dolphins in the IRL exhibit wide variation in movement ecology. Furthermore, it suggests IRL dolphins may spend much of the daytime hours traveling [8], and inlets may be important nocturnal foraging locations. Preferential use of inlets at night may not only be driven by improved prey availability at the front between estuarine and marine waters, but may also be influenced by other factors such as reduced predation pressure and decreased disturbance from human activities at night.

The only aspect of our study that was consistent for all four tagged dolphins was movement outside of the main IRL system (both into the ocean and up freshwater sources). Since there are no physical boundaries 
limiting movement, it is not surprising that dolphins range beyond the IRL. Several studies have documented other dolphin populations traveling beyond their respective study area boundaries [24, 57, 59]. However, this finding was particularly interesting because a long-term IRL dolphin photo-ID program suggested this population stayed within the IRL system and rarely ventured beyond the inlets $(<1 \mathrm{~km}$ was documented) [49]. A more recent genetic study found gene flow occurred between the IRL and ocean dolphin populations [60]. Depending upon the population, satellite telemetry and photo-ID can yield similar [61] or different [11] dolphin ranging patterns. Perhaps the differences between our study and the IRL photo-ID study [49] are simply due to nocturnal vs diurnal movements; however, the majority of the satellite locations considered outside of the IRL were in areas typically not surveyed by the photo-ID program [48]. Furthermore, satellite tags were transmitting during the summer months, a time when the IRL dolphin population is seen less frequently within the main IRL, particularly in the southern portion $[46,49,50]$. It is plausible that dolphins are seen less during the summer season in part because the animals are in the ocean or adjoining waterways where researchers typically do not survey by boat.

Data from satellite telemetry indicated that not only do IRL dolphins swim out into the ocean, but they also swim substantial distances $(\geq 20 \mathrm{~km})$ up freshwater rivers, creeks, and canals (mean salinity $=6.6 \pm 9.1 \mathrm{ppt}$ ). These do not appear to be extended stays in freshwater which can be detrimental to dolphin health [62], but instead involve many brief trips upriver. This corresponds with dolphins in Barataria Bay, LA who typically spent less than $24 \mathrm{~h}$ in salinity $<8$ ppt [14]. Other studies have documented dolphins traveling up rivers during the day $[12,59]$, and a prior study, which included several IRL dolphins, documented upriver movement at night [52]. It is also possible that movement outside of the main IRL system is a new phenomenon, perhaps in response to reduced productivity within the IRL due to the 2011 superbloom [43]. Diurnal satellite telemetry data would help determine if freshwater and ocean use by the IRL dolphin population is limited to nocturnal movements or if it is simply being missed by the other research methods. Continued telemetry data as the IRL recovers from the superbloom would help determine if movements were connected to reduced productivity.

A potential concern associated with both the frequent use of inlets and the documented movement into oceanic waters is disease transmission, including epizootic disease outbreaks. Both create opportunities for IRL dolphins to interact with ocean dolphin populations and the evidence of gene flow [60] suggests there is, in fact, interaction. This presents a risk to both dolphin populations, as diseases could spread in either direction. At the South Carolina-Georgia border, the coastal population of dolphins had higher rates of dolphin morbillivirus than the neighboring sound and estuary populations [23]. Within the last 20 years, the IRL dolphin population has experienced four separate Unusual Mortality Events (UMEs), with the most recent (morbillivirus event) impacting dolphins only in the northern portion of the IRL [46]. It is possible that inlets may be hotspots for disease transmission, which could perpetuate UMEs beyond the site of origin.

Overall, this study illustrates the important role that satellite telemetry can play in fully understanding how dolphins utilize their environment. Our study also confirms this technology can be used in extremely narrow habitats $(\sim 1 \mathrm{~km}$ wide). In addition to providing data on nocturnal movements, satellite telemetry can be extremely effective at providing a more complete assessment of ranging patterns than other methodologies, as satellite telemetry is fine-scale, not confined to a predefined study area [11], and can provide an enormous amount of data. Furthermore, estimated home range sizes often increase as the study area size is increased [63]; thus, satellite telemetry would be an ideal first step in determining the most appropriate study area boundary for specific populations. Finally, this study revealed how animal satellite telemetry in concert with individual ecological niche modeling can assist in the conservation of coastal cetaceans. It identified high-use habitats that may feature in management plans to maintain population viability and health. It may also be useful to re-access current stock boundaries for dolphin populations. For example, while evidence of mixing between the northern portion of the study area (Mosquito Lagoon) and ocean dwelling dolphins has been previously reported [60], our study further indicates that interactions between dolphins in the southern portion of the IRL and ocean stocks may occur more often than previously thought [45]. These results suggest the incorporation of satellite telemetry into long-term studies of bottlenose dolphins in other regions may provide essential information regarding dolphin movements and habitat use that is not otherwise readily available.

\section{Conclusions}

This study was the first to utilize satellite telemetry on Indian River Lagoon dolphins and documents, for the first time, nocturnal movements and habitat use of individual bottlenose dolphins in a complex estuarine system. Results indicated high individual variability in both nocturnal movement patterns and habitat selection, with some individuals exhibiting preferential use 
of inlets, seagrass habitat, and specific water depths. Variability may not only be linked to individual differences in prey preference and/or foraging strategy, but may also be influenced by social factors, differences in predator avoidance strategies, and individual response to human disturbance. Furthermore, all tagged dolphins exhibited considerable movement into the adjoining ocean and freshwater sources, revealing that the dolphins have a larger range that encompasses more habitats than previously thought. This highlights the importance of considering nocturnal data for new and ongoing research projects.

Detailed knowledge of habitat selection and ranging patterns is important for meaningful risk assessments and the implementation of effective management strategies for cetacean populations. For the IRL population, dolphins traveling into small waterways connected to the main estuarine system may have increased risk of exposure to contaminants and low salinities which can adversely impact dolphin health [62, 64]. Furthermore, these waterways are often near centers of human populations, and decreased dolphin maneuverability in narrow creeks may increase anthropogenic disturbance for these dolphins. In fact, dolphins in the southern portion of the Indian River have a higher rate of propeller strike wounds than other regions of the IRL [33]. Future efforts should focus on public outreach which may help decrease these harmful interactions in this region. Dolphins traveling into the ocean increase the possibility of contact and gene flow with other dolphin populations, potentially altering the fitness of the IRL population by increasing genetic diversity, and may also expose estuarine dolphins to different threats including potential epizootic disease $[23,65]$. This was evident during the 2013-2015 mid-Atlantic morbillivirus epidemic when the virus affected dolphins inhabiting the adjacent estuarine waters [45]. Researchers monitoring future epizootic events should be prepared for this potential given the utilization of inlet habitat and oceanic waters observed in this study.

Continued satellite-linked tagging efforts of the IRL dolphin population are needed to gain further insight into both nocturnal and diurnal movement patterns and habitat use. While any form of research can potentially have an impact on behavior, the physical effects of single pin tag attachments are often minimal [66]. Also, health assessments have been regularly conducted on the IRL dolphin population, providing easy tagging opportunities. Therefore, further research including a larger sample size, tagging in multiple seasons, and setting the tags to collect both diurnal and nocturnal datasets would greatly contribute to enhancing our knowledge of dolphin ecology in the region.

\section{Methods}

\section{Study area}

This study was conducted within the Indian River Lagoon (IRL), an extremely shallow estuarine system stretching approximately $250 \mathrm{~km}\left(876 \mathrm{~km}^{2}\right)$ along the east coast of Florida (Fig. 1). The IRL consists of four interconnected bodies of water: Mosquito Lagoon, Banana River, Indian River, and the St. Lucie River (SLR) which runs E-W off the Indian River in the southern portion of the lagoon. The estuary is connected to the ocean via five inlets (Ponce de Leon, Sebastian, Fort Pierce, St. Lucie, and Jupiter Inlets) that facilitate salt water exchange while numerous small rivers, creeks, and canals release freshwater into the IRL. This results in substantially varied salinity dependent upon tide, inlet proximity, and freshwater inflow. The average depth of the IRL is approximately $1 \mathrm{~m}$; however, a dredged channel (Intracoastal Waterway) runs the entire length of the lagoon that is substantially deeper $(>3 \mathrm{~m})$. The estuary is also quite narrow, with widths ranging from approximately 1-9 km [55] and spoil islands are scattered throughout the lagoon.

\section{Tag application}

During a dolphin health and environmental risk assessment conducted within the IRL in June 2012, dolphins were temporarily captured and restrained using standardized methods [67]. Satellite tags (SPOT 100 tags, Wildlife Computers) were attached on the lower third of the trailing edge of the dorsal fin of four male dolphins, aged 6-21 years (Additional file 2). Age was estimated either by counting growth layer groups (GLGs) in teeth, or based upon photo-identification survey data. Using methods similar to those previously described $[61,68]$, the attachment site on the dorsal fin was prepared by cleansing with chlorhexidine scrub (2\%) followed by methanol, and a local anesthetic (lidocaine $2 \%$ with epinephrine) was administered in the cleansed region. A sterilized stainless steel 6 - $\mathrm{mm}$ bore was then pushed through the fin into a rubber sanding block held firmly against the other side of the dorsal fin creating a round hole $32 \mathrm{~mm}$ from the trailing edge. An internally threaded sterilized delrin pin was inserted through the hole and the flanges of the tag were aligned over the center hole in the delrin pin; then a thread cutting screw and a stainless steel washer were attached to each side of the tag. Last, the function of the tag was tested and the dolphin was released.

To facilitate weekly post-release monitoring (dictated by weather), a VHF transmitter (MM 120, backmount transmitter, Advanced Telemetry Systems, Inc, Isanti, $\mathrm{MN}, \mathrm{USA}$ ) was attached to the trailing edge of the dorsal 
fin above the satellite tag in a thermoplastic sleeve (bullet tag, Trac Pac, Ft. Walton Beach, FL) on one individual (HEMA, Additional file 2). In brief, the site was cleansed and a local anesthetic was administered as described above. A small hole was then pierced $25 \mathrm{~mm}$ from the trailing edge of the fin using a sterile 5 -mm biopsy punch, and a sterilized delrin pin $(0.64 \mathrm{~cm})$ was then passed through the piercing and fastened to the bullet sleeve with non-stainless steel nuts and stainless steel washers. The VHF transmitter enabled focal follows to be conducted during the same relative time frame that satellite telemetry data were being collected. Using previously described methods [8], radio tracking was conducted by vessel, during the daylight hours, and within the main IRL system.

\section{Satellite-linked telemetry}

The satellite tags recorded location data via the Argos satellite system. The tags were set to transmit constantly until 250 transmissions were reached in each 24-h cycle. We chose to limit the number of daily transmissions not only to focus on nocturnal behavior, but also to extend the longevity of the tags in order to gain sufficient statistical power for scientific inference. Wildlife Computer's DAP processor was used to convert the transmission data into a usable format. Since the precision of Argos satellite positions depends on the number of uplinks during each satellite pass, data were first filtered to only include the location quality classes of 1 (position accuracy $<1500 \mathrm{~m}$ ), 2 (position accuracy $<500 \mathrm{~m}$ ), and 3 (position accuracy $<250 \mathrm{~m})$. Then, the data were quality checked even further by assessing whether the data points were possible based upon swim speed. Estimated swim speeds were calculated using the time and distance between each high-quality satellite location. If the data suggested an unreasonable swim speed or a specific speed for an unreasonable amount of time, the location was removed from the dataset. According to Williams et al. [69], the exertion of swimming $2.1 \mathrm{~ms}^{-1}$ varied little from resting; therefore, we assumed this speed could be sustained indefinitely, regardless of how much time had passed between satellite locations (the maximum duration between locations was $154 \mathrm{~h}$ ). Most of our data (98.4\%) fell into this speed category, with higher speeds averaging only $20 \mathrm{~min}$ in duration. Lang [70] reported sustainable swim speeds of $3.1 \mathrm{~ms}^{-1}$, Noren et al. [71] reported mean adult swim speeds of $3.88 \mathrm{~ms}^{-1}$, and Johannessen and Harder [72] reported higher speeds of $8.8-9.3 \mathrm{~ms}^{-1}$ for 25 min durations. Thus, we assumed speeds of $3.8 \mathrm{~ms}^{-1}$ could be sustained for $<45 \mathrm{~min}$ and $3.4 \mathrm{~ms}^{-1}$ could be sustained for $<1.5 \mathrm{~h}$. Using these criteria, a total of 53 data points were removed from the dataset. This process was completed to give the most conservative assessment of the data. After completing the assessments above, to help reduce autocorrelation among satellite fixes, the data were filtered so that locations were $\geq 1 \mathrm{~h}$ apart, resulting in the removal of an additional 653 data points.

\section{Analyses \\ Individual home range use}

Each individual's nocturnal fixed kernel density home range [73] was estimated (bandwidth $=$ ad hoc method, grid $=100$ ) using the adehabitatHR package [74] in $R$ [75]. AdehabitatHR contains functions dealing with home range analysis, and is especially useful for the analysis of relocation data collected via VHF/GPS collars or satellite tags. The entire home range was defined as the $95 \%$ contour, and the $50 \%$ contour represented the core area. Home ranges and core areas were then mapped using QGIS software [76]. To help further visualize the general movement patterns, we graphed UTM Northing vs date for each dolphin. Since the IRL is extremely narrow, the majority of dolphin movement was north-south.

\section{Travel outside the main IRL system}

Since the IRL is not a geographically closed system and is connected via inlets to the ocean, as well as to freshwater rivers and canals (salinity: 6.6 $\pm 9.1 \mathrm{ppt}$ during tagging period; raw data obtained from St. Johns River and South Florida Water Management Districts), we investigated whether dolphins moved outside of the commonly surveyed portions of the IRL system at night. Satellite data are not exact; therefore, the Argos error of each location was used to determine if locations potentially fell within the IRL. Whenever possible, locations were assumed to be within the IRL and only data where the entire error buffer did not touch the IRL were deemed 'outside'. This represents the most conservative estimate of movement outside of the main IRL system. Utilizing detailed hydrography maps and the Road Graph plugin in QGIS, travel distances (how far dolphins traveled up river or out into the ocean) were measured as the shortest possible route to get from the edge of the IRL to the nearest edge of each location.

\section{Habitat selection}

To assess the potential importance of three habitat types hypothesized to be valuable to dolphins at night (inlets, seagrass beds, and water depth), we ran binomial tests using the stats package in $R$ [75] to determine if each habitat type was used more often than expected based upon its availability within the animal's home range. We used the number of satellite locations within each habitat type as an estimate of time spent in that habitat. We defined inlet habitat as areas that were within $5 \mathrm{~km}$ of the opening to the ocean. Using QGIS, a $5-\mathrm{km}$ buffer 
was created around the central point (i.e., the center of the gap in land) of each of the five inlets. The number of dolphin locations that fell within these inlet habitats were the observed values, while the expected values were calculated from the proportion of each dolphin's entire home range that occurred within the $5-\mathrm{km}$ inlet buffers.

Seagrass data were acquired from St. John's River Water Management District. As the available seagrass data fell only within the IRL system, home ranges and dolphin locations were clipped so they did not include ocean habitat or any of the small waterways for this analysis. Then, we counted the number of dolphin locations within seagrass (observed values) and calculated the expected values based on the proportion of each animal's clipped home range that contained seagrass.

Depth was evaluated using a depth raster and contours created from sounding data obtained from St. Johns River and South Florida Water Management Districts. Depth data outside of the IRL were not available; therefore, we can make no assumptions about depth preferences in small waterways or the ocean. To test for IRL depth preferences, we first grouped depth into four categories: $<1 \mathrm{~m}, 1-2 \mathrm{~m}, 2-3 \mathrm{~m}$, and $>3 \mathrm{~m}$, to facilitate comparison with a recent radio-telemetry study of diurnal ranging patterns and habitat use of dolphins in the IRL [8]. Then, we clipped home ranges as in the seagrass analysis above, counted the number of dolphin locations within each depth category (observed values), and calculated expected values based on the proportion of each animal's clipped home range that fell within each depth category.

\section{Ecological niche modeling}

To further investigate the influence of environmental features on dolphin distribution and ranging patterns, we conducted maximum entropy (MaxEnt) modeling for each dolphin using MaxEnt 3.4.1 [77, 78]. MaxEnt is a machine-learning technique that can use location data on a species in conjunction with detailed environmental data to infer what environmental features influence species distributions and define species niches. Thus, it can be used to predict conditions that are suitable for a species $[77,79,80]$. MaxEnt is a powerful predictive modeling method when there are presence-only data [79], sample sizes are small [81], and data are prone to positioning errors [82], all of which are often true for satellite telemetry data.

Here, we apply this method to predicting and comparing environmental conditions favored by each tagged dolphin within the IRL and adjoining waters. We ran models for individual dolphins incorporating the following environmental variables: monthly sea surface temperature (SST), monthly dissolved oxygen (DO), type of water body (i.e., brackish, freshwater, or ocean), seagrass habitat, distance from seagrass habitat, distance from inlets, map of small waterways, and distance from small waterways. Small waterways were considered any river, creek, or canal connected to the IRL system, which encompassed a large range of salinities $(6.6 \pm 9.1 \mathrm{ppt}$ during tagging period; raw data from St. Johns and South Florida Water Management districts) depending upon location (i.e., upriver vs river mouth). Depth was not incorporated in the models since depth data were only available for the IRL and MaxEnt software omitted all data points outside the IRL when depth was included. For each model, 75\% of the location data were chosen at random and used to train the model while the remaining $25 \%$ were used for testing. We used a Cloglog output for all models, created response curves for each variable, and jackknife analyses were conducted to test the importance of each environmental variable. Rasters of each environmental parameter were created using data obtained from St. Johns River and South Florida Water Management Districts (all IRL and small waterway data) and the World Oceans Atlas (ocean SST [83], ocean DO [84]). All rasters were created in QGIS using a cell size of $25 \mathrm{~m}$ and a rectangular extent which encompassed all our data points plus the entire IRL system. The 'distance from' variables were simply a distance raster created using the above parameters.

\section{Supplementary information}

Supplementary information accompanies this paper at https://doi. org/10.1186/s40317-020-00200-4.

Additional file 1. MaxEnt Jackknife analyses and response curves. Figures from the MaxEnt models for each dolphin depicting the results of the jackknife analysis of variable importance and the response curves for each environmental variable.

Additional file 2. Advanced telemetry systems, Inc MM $120 \mathrm{VHF}$ radio transmitter (upper) and Wildlife Computers SPOT 100 satellite transmitter (lower) attached to the trailing edge of HEMA's dorsal fin.

\section{Abbreviations}

AUC: Area under the receiving operating curve; DO: Dissolved oxygen; GLG: Growth layer groups; IRL: Indian River Lagoon; SFWMD: South Florida Water Management District; SJRWMD: St. Johns River Water Management District; SLR: St. Lucie River; SST: Sea surface temperature; UME: Unusual mortality event; UTM: Universal Transverse Mercator.

\section{Acknowledgements}

Tagging methods were approved under US National Marine Fisheries Service Scientific Research Permit Nos. 998-1678 and 14352 issued to Dr Greg Bossart and Florida Atlantic University IACUC protocol number A10-13. Additional details for specific health-related findings can be found in previous publications as cited. A special thank you goes to Lydia Moreland and Teresa Jablonski for providing invaluable assistance in the field during HEMA's radio tracking. We would also like to thank Stephen McCulloch for his assistance during tagging operations and Marilyn Mazzoil for providing photo-ID age estimates for some of the dolphins. A final thank you goes to the St. Johns River Water Management District (SJRWMD) and South Florida Water Management District (SFWMD) for providing essential environmental data on the Indian River Lagoon. In specific, much of the depth data were supplied by SJRWMD 
from a bathymetric survey performed for the District by Coastal Planning \& Engineering. All other environmental data were supplied freely on SJRWMD or SFWMD's websites. We would like to thank Harbor Branch Oceanographic Institute, Florida Atlantic Univeristy and the Harbor Branch Oceanographic Institute Foundation for their support.

\section{Authors' contributions}

GOCC and WND assisted with tagging the dolphins. WND conducted the radio-tracking and supplied the radio-telemetry data. EFH completed the QA/ QC of the data and all data analyses. EFH wrote the manuscript, while GOCC and WND supplied substantial editorial advice for the final manuscript. All authors read and approved the final manuscript.

\section{Funding}

Funding for this project was provided from proceeds of both the Protect Wild Dolphins and Discover Florida's Oceans specialty license plates with support from the SeaWorld and Busch Gardens Conservation Fund.

\section{Availability of data and materials}

The datasets used and/or analyzed during the current study are available from the corresponding author on reasonable request.

\section{Ethics approval and consent to participate}

Research was conducted under NMFS Scientific Research Permit Numbers 15631, 16522, 14352 and NMFS General Authorization No. 32. All tagging methods were approved under US National Marine Fisheries Service Scientific Research Permit Numbers 998-1678 and 14352 issued to G. Bossart and Florida Atlantic University IACUC protocol number A10-13.

\section{Consent for publication}

Not applicable.

\section{Competing interests}

The authors declare that they have no competing interests.

\section{Author details}

1 Seven Degrees of Mapping LLC, 810 Laurel Meadows Pkwy, Greenville, SC 29607, USA. ${ }^{2}$ Hubbs-SeaWorld Research Institute, 3830 South Hwy A1A \#4-181, Melbourne Beach, FL 32951, USA. ${ }^{3}$ Harbor Branch Oceanographic Institute at Florida Atlantic University, 5600 US 1 North, Fort Pierce, FL 34946, USA.

Received: 18 November 2019 Accepted: 24 April 2020

Published online: 30 April 2020

\section{References}

1. Atem ACG, Monteiro-Filho ELA. Nocturnal activity of the estuarine dolphin (Sotalia guianensis) in the region of Cananéia, São Paulo State, Brazil. Aquat Mamm. 2006;32(2):236-41.

2. Klatsky LJ, Wells RS, Sweeney JC. Offshore bottlenose dolphins (Tursiops truncatus): movement and dive behavior near the Bermuda Pedestal. J Mammal. 2007:88(1):59-66.

3. Dede A, Öztürk AA, Akamatsu T, Tonay AM, Öztürk B. Long-term passive acoustic monitoring revealed seasonal and diel patterns of cetacean presence in the Istanbul Strait. J Mar Biol Assoc UK. 2014;94(6):1195-202.

4. Herzing DL, Elliser CR. Nocturnal feeding of Atlantic spotted dolphins (Stenella frontalis) in the Bahamas. Mar Mamm Sci. 2014;30(1):367-73.

5. McHugh KA, Allen JB, Barleycorn AA, Wells RS. Severe Karenia brevis red tides influence juvenile bottlenose dolphin (Tursiops truncatus) behavior in Sarasota Bay, Florida. Mar Mamm Sci. 2011;27(3):622-43.

6. Powell JR, Wells RS. Recreational fishing depredation and associated behaviors involving common bottlenose dolphins (Tursiops truncatus) in Sarasota Bay, Florida. Mar Mamm Sci. 2011;27(1):111-29.

7. Titcomb EM, O'Corry-Crowe G, Hartel EF, Mazzoil MS. Social communities and spatiotemporal dynamics of association patterns in estuarine bottlenose dolphins. Mar Mamm Sci. 2015;31(4):1314-37.

8. Durden WN, O'Corry-Crowe G, Shippee S, Jablonski T, Rodgers S, Mazzoil $M$, et al. Small-scale movement patterns, activity budgets, and association patterns of radio-tagged Indian River Lagoon bottlenose dolphins (Tursiops truncatus). Aquat Mamm. 2019;45(1):66-87.

9. Tyne JA, Johnston DW, Rankin R, Loneragan NR, Bejder L. The importance of spinner dolphin (Stenella longirostris) resting habitat: implications for management. J Appl Ecol. 2015;52:621-30.

10. Deconto LS, Monteiro-Filho ELA. Day and night sounds of the Guiana dolphin, Sotalia guianensis (Cetacea: Delphinidae) in southeastern Brazil. Acta Ethol. 2016;19(1):61-8.

11. Balmer BC, Wells RS, Schwacke LH, Schwacke JH, Danielson B, George $R C$, et al. Integrating multiple techniques to identify stock boundaries of common bottlenose dolphins (Tursiops truncatus): techniques to identify bottlenose dolphin stock boundaries. Aquat Conserv Mar Freshw Ecosyst. 2013;24(4):511-21.

12. Young RF, Phillips HD. Primary production required to support bottlenose dolphins in a salt marsh estuarine creek system. Mar Mamm Sci. 2002;18(2):358-73.

13. Fury CA, Harrison PL. Seasonal variation and tidal influences on estuarine use by bottlenose dolphins (Tursiops aduncus). Estuar Coast Shelf Sci. 2011;93(4):389-95.

14. Hornsby F, McDonald T, Balmer B, Speakman T, Mullin K, Rosel P, et al. Using salinity to identify common bottlenose dolphin habitat in Barataria Bay, Louisiana, USA. Endanger Species Res. 2017;33:181-92.

15. Wilson B, Thompson PM, Hammond PS. Habitat use by bottlenose dolphins: seasonal distribution and stratified movement patterns in the Moray Firth, Scotland. J Appl Ecol. 1997;34(6):1365-74.

16. Rossman S, Berens McCabe E, Barros NB, Gandhi H, Ostrom PH, Stricker $\mathrm{CA}$, et al. Foraging habits in a generalist predator: sex and age influence habitat selection and resource use among bottlenose dolphins (Tursiops truncatus). Mar Mamm Sci. 2015;31(1):155-68.

17. Marley SA, Salgado Kent CP, Erbe C. Occupancy of bottlenose dolphins (Tursiops aduncus) in relation to vessel traffic, dredging, and environmental variables within a highly urbanised estuary. Hydrobiologia. 2017;792(1):243-63.

18. Allen M, Read A, Gaudet J, Sayigh L. Fine-scale habitat selection of foraging bottlenose dolphins Tursiops truncatus near Clearwater, Florida. Mar Ecol Prog Ser. 2001;222:253-64.

19. Irvine AB, Scott MD, Wells RS, Kaufmann JH. Movements and activities of the Atlantic bottlenose dolphin, Tursiops truncatus. Fish Bull. 1981;79(4):671-88.

20. Heithaus MR, Dill LM. Food availability and tiger shark predation risk influence bottlenose dolphin habitat use. Ecology. 2002;83(2):480-91.

21. Vermeulen E. Intertidal habitat use of bottlenose dolphins (Tursiops truncatus) in Bahía San Antonio, Argentina. J Mar Biol Assoc UK. 2018;98(5):1109-18.

22. Chilvers BL, Corkeron PJ. Trawling and bottlenose dolphins' social structure. Proc R Soc Lond B Biol Sci. 2001;268:1901-5.

23. Balmer B, Zolman E, Rowles T, Smith C, Townsend F, Fauquier D, et al. Ranging patterns, spatial overlap, and association with dolphin morbillivirus exposure in common bottlenose dolphins (Tursiops truncatus) along the Georgia, USA coast. Ecol Evol. 2018;8:12890-904.

24. Ingram S, Rogan E. Identifying critical areas and habitat preferences of bottlenose dolphins Tursiops truncatus. Mar Ecol Prog Ser. 2002:244:247-55.

25. Sarabia RE, Heithaus MR, Kiszka JJ. Spatial and temporal variation in abundance, group size and behaviour of bottlenose dolphins in the Florida coastal Everglades. J Mar Biol Assoc UK. 2018;98(5):1097-107.

26. Sprogis KR, Christiansen F, Raudino HC, Kobryn HT, Wells RS, Bejder L. Sex-specific differences in the seasonal habitat use of a coastal dolphin population. Biodivers Conserv. 2018;27(14):3637-56.

27. Fair PA, Adams J, Mitchum G, Hulsey TC, Reif JS, Houde M, et al. Contaminant blubber burdens in Atlantic bottlenose dolphins (Tursiops truncatus) from two southeastern US estuarine areas: concentrations and patterns of PCBs, pesticides, PBDEs, PFCs, and PAHs. Sci Total Environ. 2010;408(7):1577-97.

28. Schwacke LH, Smith CR, Townsend FI, Wells RS, Hart LB, Balmer BC, et al. Health of common bottlenose dolphins (Tursiops truncatus) in Barataria Bay, Louisiana, following the Deepwater Horizon oil spill. Environ Sci Technol. 2014;48(1):93-103.

29. Constantine R, Brunton DH, Dennis T. Dolphin-watching tour boats change bottlenose dolphin (Tursiops truncatus) behaviour. Biol Conserv. 2004;117(3):299-307. 
30. Bejder L, Samuels A, Whitehead H, Gales N, Mann J, Connor R, et al. Decline in relative abundance of bottlenose dolphins exposed to longterm disturbance. Conserv Biol. 2006;20(6):1791-8.

31. Lemon M, Lynch TP, Cato DH, Harcourt RG. Response of travelling bottlenose dolphins (Tursiops aduncus) to experimental approaches by a powerboat in Jervis Bay, New South Wales, Australia. Biol Conserv. 2006;127(4):363-72.

32. Pirotta E, Merchant ND, Thompson PM, Barton TR, Lusseau D. Quantifying the effect of boat disturbance on bottlenose dolphin foraging activity. Biol Conserv. 2015;181:82-9.

33. Bechdel SE, Mazzoil MS, Murdoch ME, Howells EM, Reif JS, McCulloch SD, et al. Prevalence and impacts of motorized vessels on bottlenose dolphins (Tursiops truncatus) in the Indian River Lagoon, Florida. Aquat Mamm. 2009;35(3):367-77.

34. Dwyer S, Kozmian-Ledward L, Stockin K. Short-term survival of severe propeller strike injuries and observations on wound progression in a bottlenose dolphin. N Z J Mar Freshw Res. 2014;48(2):294-302.

35. Mann J, Smolker RA, Smuts BB. Responses to calf entanglement in freeranging bottlenose dolphins. Mar Mamm Sci. 1995;11(1):100-6.

36. Barco SG, D'Eri LR, Woodward BL, Winn JP, Rotstein DS. Spectra ${ }^{\circledR}$ fishing twine entanglement of a bottlenose dolphin: a case study and experimental modeling. Mar Pollut Bull. 2010;60(9):1477-81.

37. Stolen M, Noke Durden W, Mazza T, Barros N, Leger J. Effects of fishing gear on bottlenose dolphins (Tursiops truncatus) in the Indian River Lagoon system, Florida. Mar Mamm Sci. 2013;29(2):356-64.

38. Barros NB, Wells RS. Prey and feeding patterns of resident bottlenose dolphins (Tursiops truncatus) in Sarasota Bay, Florida. J Mammal. 1998;79(3):1045-59.

39. Sargeant BL, Wirsing AJ, Heithaus MR, Mann J. Can environmental heterogeneity explain individual foraging variation in wild bottlenose dolphins (Tursiops sp.)? Behav Ecol Sociobiol. 2007;61 (5):679-88.

40. Tyne J, Loneragan N, Kopps A, Allen S, Krützen M, Bejder L. Ecological characteristics contribute to sponge distribution and tool use in bottlenose dolphins Tursiops sp. Mar Ecol Prog Ser. 2012;444:143-53.

41. Torres LG, Read AJ. Where to catch a fish? The influence of foraging tactics on the ecology of bottlenose dolphins (Tursiops truncatus) in Florida Bay, Florida. Mar Mamm Sci. 2009;25(4):797-815.

42. Fletcher SW, Fletcher WW. Factors affecting changes in seagrass distribution and diversity patterns in the Indian River Lagoon complex between 1940 and 1992. Bull Mar Sci. 1995;57(1):49-58.

43. St Johns River Water Management District, Bethune-Cookman University, Florida Atlantic University-Harbor Branch Oceanographic Institution, Florida Fish and Wildlife Conservation Commission, Florida Institute of Technology, Nova Southeastern University, et al. Indian River Lagoon 2011 Superbloom: Plan of Investigation. 2012. https:// www.sjrwmd.com/static/waterways/irl-technical//2011superbloom_ investigationplan_June_2012.pdf.

44. Indian River Lagoon National Estuary Program. Indian River Lagoon: An introduction to a natural treasure. 2007. https://www.epa.gov/sites /production/files/2018-01/documents/58692_an_river_lagoon_an_ introduction_to_a_natural_treasure_2007.pdf.

45. Waring GT, Josephson E, Maze-Foley K, Rosel PE. US Atlantic and Gulf of Mexico marine mammal stock assessments-2015. National Marine Fisheries Service: 166 Water Street, Woods Hole, MA 02543; p. 501. Report No.: NOAA Tech Memo NMFS-NE-238. https://doi.org/10.7289/ v57s7ktn.

46. Durden WN, Stolen ED, Jablonski TA, Puckett SA, Stolen MK. Monitoring seasonal abundance of Indian River Lagoon bottlenose dolphins (Tursiops truncatus) using aerial surveys. Aquat Mamm. 2017;43(1):90-112.

47. Mazzoil M, McCulloch SD, Defran RH, Murdoch ME. Use of digital photography and analysis of dorsal fins for photo-identification of bottlenose dolphins. Aquat Mamm. 2004;30(2):209-19.

48. Mazzoil M, Reif JS, Youngbluth M, Murdoch ME, Bechdel SE, Howells E, et al. Home ranges of bottlenose dolphins (Tursiops truncatus) in the Indian River Lagoon, Florida: environmental correlates and implications for management strategies. EcoHealth. 2008;5(3):278-88.

49. Mazzoil M, Murdoch ME, Reif JS, Bechdel SE, Howells E, de Sieyes M, et al. Site fidelity and movement of bottlenose dolphins (Tursiops truncatus) on Florida's east coast: atlantic Ocean and Indian River Lagoon estuary. Fla Sci. 2011;74(1):25-37.
50. Durden WN, Stolen ED, Stolen MK. Abundance, distribution, and group composition of Indian River Lagoon bottlenose dolphins (Tursiops truncatus). Aquat Mamm. 2011;37(2):175-86.

51. Mazzoil MS, McCulloch SD, Youngbluth MJ, Kilpatrick DS, Murdoch EM, Mase-Guthrie B, et al. Radio-tracking and survivorship of two rehabilitated bottlenose dolphins (Tursiops truncatus) in the Indian River Lagoon, Florida. Aquat Mamm. 2008;34(1):54-64.

52. Shippee SF. Movements, fishery interactions, and unusual mortalities of bottlenose dolphins [Doctoral dissertation]. [Orlando, FL]: University of Central Florida; 2014.

53. Mullin KD, McDonald T, Wells RS, Balmer BC, Speakman T, Sinclair C, et al. Density, abundance, survival, and ranging patterns of common bottlenose dolphins (Tursiops truncatus) in Mississippi Sound following the Deepwater Horizon oil spill. PLoS ONE. 2017;12(10):e0186265.

54. Curtis TH, Adams DH, Burgess GH. Seasonal distribution and habitat associations of bull sharks in the Indian River Lagoon, Florida: a 30-year synthesis. Trans Am Fish Soc. 2011;140(5):1213-26.

55. Gilmore RG, Donohoe CJ, Cooke DW. Fishes of the Indian River Lagoon and adjacent waters, Florida. 1981. (Harbor Branch Foundation, Inc.). Report No.: 41.

56. Parra GJ. Resource partitioning in sympatric delphinids: space use and habitat preferences of Australian snubfin and Indo-Pacific humpback dolphins. J Anim Ecol. 2006;75(4):862-74.

57. Ballance LT. Habitat use patterns and ranges of the bottlenose dolphin in the Gulf of California, Mexico. Mar Mamm Sci. 1992;8(3):262-74.

58. Jones GJ, Sayigh LS. Geographic variation in rates of vocal production of free-ranging bottlenose dolphins. Mar Mamm Sci. 2002;18(2):374-93.

59. Fury CA, Harrison PL. Abundance, site fidelity and range patterns of Indo-Pacific bottlenose dolphins (Tursiops aduncus) in two Australian subtropical estuaries. Mar Freshw Res. 2008;59(11):1015-27.

60. Rodgers SE. Population structure and dispersal of bottlenose dolphins (Tursiops truncatus) of the Indian River Lagoon estuary, Florida, and adjacent Atlantic waters [MSc]. [Boca Raton, FL]: Florida Atlantic University; 2013.

61. Wells R, Schwacke L, Rowles T, Balmer B, Zolman E, Speakman T, et al. Ranging patterns of common bottlenose dolphins Tursiops truncatus in Barataria Bay, Louisiana, following the Deepwater Horizon oil spill. Endang Species Res. 2017;33:159-80.

62. Ewing RY, Mase-Guthrie B, MCFee W, Townsend F, Manire CA, Walsh M, et al. Evaluation of serum for pathophysiological effects of prolonged low salinity water exposure in displaced bottlenose dolphins (Tursiops truncatus). Front Vet Sci. 2017:4:80

63. Nekolny SR, Denny M, Biedenbach G, Howells EM, Mazzoil M, Durden $W N$, et al. Effects of study area size on home range estimates of common bottlenose dolphins Tursiops truncatus. Curr Zool. 2017;63(6):693-701.

64. Lahvis GP, Wells RS, Kuehl DW, Stewart JL, Rhinehart HL, Via CS. Decreased lymphocyte responses in free-ranging bottlenose dolphins (Tursiops truncatus) are associated with increased concentrations of PCBs and DDT in peripheral blood. Environ Health Perspect. 1995;103(suppl 4):67-72.

65. Morris SE, Zelner JL, Fauquier DA, Rowles TK, Rosel PE, Gulland F, et al. Partially observed epidemics in wildlife hosts: modelling an outbreak of dolphin morbillivirus in the northwestern Atlantic, June 2013-2014. J R Soc Interface. 2015;12(112):20150676.

66. Balmer BC, Wells RS, Schwacke LH, Rowles TK, Hunter C, Zolman ES, et al. Evaluation of a Single-Pin, Satellite-Linked Transmitter Deployed on Bottlenose Dolphins (Tursiops truncatus) Along the Coast of Georgia, USA. Aquat Mamm. 2011;37(2):187-92.

67. Fair PA, Adams JD, Zolman E, McCulloch SD, Juli D Goldstein, Murdoch $\mathrm{ME}$, et al. Protocols for conducting dolphin capture-release health assessment studies. 2006 p. 83. (NOAA Technical Memorandum NOS NCCOS 49).

68. Balmer BC, Wells RS, Howle LE, Barleycorn AA, McLellan WA, Ann Pabst D, et al. Advances in cetacean telemetry: a review of single-pin transmitter attachment techniques on small cetaceans and development of a new satellite-linked transmitter design. Mar Mamm Sci. 2014;30(2):656-73.

69. Williams TM, FriedI WA, Haun JE. The physiology of bottlenose dolphins (Tursiops truncatus): heart rate, metabolic rate and plasma lactate concentration during exercise. J Exp Biol. 1993;179(1):31-46.

70. Lang TG. Speed, power, and drag measurements of dolphins and porpoises. In: Wu TY-T, Brokaw CJ, Brennen C, editors. Swimming and flying in nature. Boston: Springer; 1975. p. 553-72. 
71. Noren SR, Biedenbach G, Edwards EF. Ontogeny of swim performance and mechanics in bottlenose dolphins (Tursiops truncatus). J Exp Biol. 2006;209:4724-31.

72. Johannessen CL, Harder JA. Sustained swimming speeds of dolphins. Science. 1960;132(3439):1550-1.

73. Worton BJ. Kernel methods for estimating the utilization distribution in home-range studies. Ecology. 1989;70(1):164-8.

74. Calenge C. The package "adehabitat" for the R software: a tool for the analysis of space and habitat use by animals. Ecol Modell. 2006;197(3):516-9.

75. R Core Team. R: a language and environment for statistical computing Vienna, Austria: R Foundation for Statistical Computing; 2014. http:// www.R-project.org/.

76. QGIS Development Team. QGIS Geographic Information System: Open Source Geospatial Foundation Project. 2016. http://qgis.osgeo.org.

77. Phillips SJ, Dudík M, Schapire RE. Maxent software for modeling species niches and distributions. 2019. http://biodiversityinformatics.amnh.org/ open_source/maxent/. Accessed Jan 182019.

78. Phillips SJ, Anderson RP, Dudík M, Schapire RE, Blair ME. Opening the black box: an open-source release of Maxent. Ecography. 2017:40(7):887-93.

79. Phillips SJ, Anderson RP, Schapire RE. Maximum entropy modeling of species geographic distributions. Ecol Modell. 2006;190(3-4):231-59.
80. Merow C, Smith MJ, Silander JA. A practical guide to MaxEnt for modeling species' distributions: what it does, and why inputs and settings matter. Ecography. 2013;36(10):1058-69.

81. Elith J, Graham HC, Anderson PR, Dudík M, Ferrier S, Guisan A, et al. Novel methods improve prediction of species' distributions from occurrence data. Ecography. 2006;29(2):129-51.

82. Graham CH, Elith J, Hijmans RJ, Guisan A, Townsend Peterson A, Loiselle $B A$, et al. The influence of spatial errors in species occurrence data used in distribution models: spatial error in occurrence data for predictive modelling. J Appl Ecol. 2008;45(1):239-47.

83. Locarnini RA, Mishonov AV, Antonov Jl, Boyer TP, Garcia HE, Baranova OK, et al. World Ocean Atlas 2013, Volume 1: Temperature. 2013. p. 40. (Levitus S, Mishonov AV, editors. NOAA Atlas NESDIS 73).

84. Garcia HE, Locarnini RA, Boyer TP, Antonov Jl, Mishonov AV, Baranova OK, et al. World Ocean Atlas 2013, Volume 3: Dissolved, apparent oxygen utilization, and oxygen saturation. 2013. p. 27. (Levitus S, Mishonov AV, editors. NOAA Atlas NESDIS 75).

\section{Publisher's Note}

Springer Nature remains neutral with regard to jurisdictional claims in published maps and institutional affiliations.
Ready to submit your research? Choose BMC and benefit from:

- fast, convenient online submission

- thorough peer review by experienced researchers in your field

- rapid publication on acceptance

- support for research data, including large and complex data types

- gold Open Access which fosters wider collaboration and increased citations

- maximum visibility for your research: over 100M website views per year

At BMC, research is always in progress.

Learn more biomedcentral.com/submissions 